Asep Jamaludin, Sihabudin, Haerudin, Asep Darojatul Ramli

Vol 5 No 1

ISSN : 2541-6995

E ISSN : 2580-5517

\title{
Peran Manajemen Pesantren Dalam Upaya Menangkal Paham Radikal Negatif Terhadap Santri \\ Asep Jamaludin ${ }^{1}$, Sihabudin ${ }^{2}$, Haerudin ${ }^{3}$, Asep Darojatul Ramli ${ }^{4}$ \\ Universitas Buana Perjuangan Karawang
}

\author{
Email: \\ asepjamaludin@ubpkarawang.ac.id \\ sihabudin@ubpkarawang.ac.id \\ haerudin@ubpkarawang.ac.id \\ asep.dj@ubpkarawang.ac.id
}

\begin{abstract}
Abstrak
Penelitia ini bertujuan untuk menelaah seberapa besar efektifitas peranan manajamen pendidikan dipondok pesantren Al Hikamussalafiyyah wanayasa cipulus dalam upaya untuk menangkal paham radikal negatif terhadap santri - santri. Dalam penelitian ini manajemen pondok pesantren wanayasa telah menerapkan kurikulum yang jauh dari paham radikalisme dan dari hasil kuesioner dan wawancara yang di bagikan kepada para santri menhghasilkan $99 \%$ persen bahwa santri tidak ada yang memeiliki paham radikal negatif tersebut. Objek penelitian santri - santri di pondok pesantren Al Fatih Wanayasa, Ini merupakan penelitian deskriptif kualitatif dengan metode yang digunakan yaitu studi kasus, dengan pengumpulan datanya melalui observasi, catatan lapangan, wawancara dan dokumentasi. Dari hasil penelitian ini peneliti berharap agar dapat memberikan kontribusi dan manfaat bagi semua pihak-pihak yang terkait, terutama pihak pemerintah daerah dan pondok pesantren dalam rangka menangkal paham radikalisme terhadap diri santri.
\end{abstract}

Kata Kunci : Manajemen Pesantren, Paham Radikal Negatif

\begin{abstract}
This research aims to examine the effectiveness of the role of education management in the boarding school Al Hikamussalafiyyah wanayasa cipulus in an effort to ward off negative radical understanding of the students. In this research, the management of Islamic boarding schools in Wanaayasa has implemented a curriculum that is far from radicalism and from the results of questionnaires and interviews distributed to the students resulted in 99\% percent that no one has the negative radical understanding. The object of research of students in Al Fatih Wanayasa boarding school, this is a qualitative descriptive study with the method used is a case study, by collecting data through observation, field notes, interviews and documentation. From the results of this study the researchers hope to be able to contribute and benefit to all parties concerned, especially the local government and Islamic boarding schools in order to counteract the radicalism against students.
\end{abstract}


Asep Jamaludin, Sihabudin, Haerudin, Asep Darojatul Ramli Vol 5 No 1

ISSN : 2541-6995

E ISSN : 2580-5517

Keywords: Pesantren Management, Negative Radical Understanding

\section{A. PENDAHULUAN}

Bangsa Indonesia merupakan bangsa yang pluralistik karena merangkum kebragamana agama, etnis seni tradisi, dan cara hidup. Pola kebragaman yang unik, dengan latar belakang mosaic yang memiliki ciri khas masing - masing, tidak mengurangi makna kesatuan Indonesia. (Faisal Ismail, 2014, h.32). Seperti juga yang terdapat dalam firman allah swt dalam surat $\mathrm{Al}$ hujurat ayat 13.

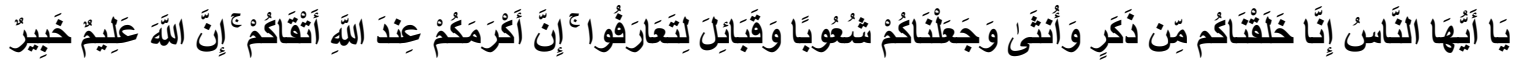
Artinya :

"Wahai manusia, sesungguhnya kami telah menciptakan kamu dari seorang laki laki dan seorang perempuan, kemudian kami jadikan kamu berbangsa - bangsa dan bersuku - suku supaya kamu saling mengenal. Sungguh, yang paling mulia diantara kamu disisi allah ialah orang yang paling bertaqwa diantara kamu. Sungguh, allah maha mengetahuai dan maha mengenal". (Departemen Agama RI, 2007, h.1382). Pada ayat diaatas diuraikan prinsip dasar antar hubungan manusia. Karena itu, ayat ini tidak lagi menggunakan panggilan yang ditujukan kepada orang-orang beriman, tetapi kepada jenis manusia. Penggalan ayat di atas sesungguhnya Kami menciptakan kamu dari seorang lakilaki dan seorang perempuan adalah pengantar untuk menegaskan bahwa semua manusia derajat kemanusiaannya sama di sisi Allah, tidak ada perbedaan antara suku yang satu dengan yang lain. Tidak ada juga perbedaan nilai kemanusiaan antara laki-laki dan perempuan (M. Quraish Shihab, Vol, 6, h.616).

Namun keragaman budaya, agama, ras, suku yang ada dindonesia terkadang membawa dampak negatif bagi warganya, salah satunya adalah pergesekan yang sering kali terjadi antara agama- agama yang berbeda, bahkan antar internal agama itu sendiri. Radikalisme, anarkisme atau kekerasan bernuansa agama cenderung terus meningkat atau setidaknya timbul tenggelam dalam beberapa tahun belakangan ini. Radikalisme yang memunculkan konflik dan kekerasan sosial bernuansa dan berlatarkan agama terus merebak bahkan sampai kepondok - pondok pesantren yang dituduh sebagai sarang teroris.

Radikalisme yang berujung pada terorisme menjadi masalah penting khususnya bagi umat Islam hari ini. Berbagai aksi teror dan pengeboman telah menyebabkan Islam dicap sebagai agama yang menyukai jalan kekerasan yang dianggap "suci" untuk menyebarkannya. Sekalipun hal ini dapat dengan mudah dimentahkan, namun fakta bahwa 
Asep Jamaludin, Sihabudin, Haerudin, Asep Darojatul Ramli Vol 5 No 1

ISSN : 2541-6995

E ISSN : 2580-5517

pelaku teror adalah seorang muslim garis keras sangat membebani psikologi umat Islam hari ini. Oleh karenanya, peran berbagai pihak dalam mengatasai berkembangnya faham radikal di Indonesia sangatlah penting dalam memberikan pemahaman islam toleran bagi masyarakat Indonesia. Dari latar belakang inilah, peneliti sangat tertarik untuk mengadakan penelitian dengan judul "Peranan Manajemen Pesantren Dalam Upaya Menangkal Paham Radikalisme"

\section{B. METODE PENELITIAN}

Penelitian ini merupakan jenis penelitian deskriptif kualitatif dengan metode yang digunakan yaitu studi kasus. Maksud dari penelitian deskriptif adalah untuk menguraikan literal ihwal manusia, kejadian, atau suatu proses yang diamati (A. Haedar, 2011,h. 26)., yang bertujuan untuk menyederhanakan realitas sosial yang kompleks agar dapat dianalisis, serta bermanfaat untuk menciptakan konsep-konsep ilmiah dan klasifikasi gejala-gejala sosial dalam masalah penelitian.(Judistira K. Gama, 2008, h. 34.). Penelitian Kualitatif adalah penelitian yang menghasilkan data deskriptif berupa kata-kata yang tertulis, atau kata-kata lisan dari orang-orang dan perilaku yang diamati.(S. Margono, 1997, h. 36). Data yang akan diperoleh dalam penelitian ini adalah : data observasi, data wawancara/angket, dan data dokumentasi. Model analisis data yang digunakan dalam penelitian ini adalah model interaktif yang dikembangkan oleh Miles dan Huberman yang dimulai dengan pengumpulan data, reduksi data, penyajian data, dan penarikan kesimpulan/verifikasi.( Wahyu, 1996, h. 61). Proses analisis data dilakukan secara terusmenerus di dalam proses pengumpulan data selama penelitian berlangsung. Pengujian keabsahan data dilakukan dengan menggunakan teknik triangulasi.

\section{Hasil Penelitian Dan Pembahasan}

\section{Sejarah Pondok Pesantrean Al hikamussalafiyyah Cipulus}

Pesantren cipulus pertama berdirinya pada tahun 1840,didirikan oleh K.H Ahmad Bin Kyai Nurkoyyim yang akrab dengan panggilan ajengan Emed, Ia santri kesayangan Maulana Syeh yusuf, Ulama dan pahlawan besar di Jawa Barat pada awal abad Ke - 19, ajengan Emed merupakan santri yang rajin,memiliki jiwa kepemimpinan yang tinggi,sehingga ia dapat dengan mudah menyerap ilmu - ilmu yang diberikan oleh gurunya,baik ilmu agama maupun ilmu strategi perang dan ilmu - ilmu lainnya yang dibutuhkan dimasa itu.Ketika belanda gencar melakukan tekananan terhadap rakyat Indonesia,Ia bertekad mendirikan sebuah pesantren. Tujuaannya menghimpun para santri untuk menyebarkan agama islam dan membantu meraih kemerdekaan. Dengan bekal ilmu 
Asep Jamaludin, Sihabudin, Haerudin, Asep Darojatul Ramli Vol 5 No 1

ISSN : 2541-6995

E ISSN : 2580-5517

yang ia miliki ditahun 1840 didirikanlah sebuah pesantren yang sederhana diwilayah bekas ibu kota karawang, dikecamatan wanayasa kabupaten purwakarta sekarang. Pesantren tersebut dipegang langsung oleh ajengan Emed hingga akhir hayatnya,setelah Ia wafat pesantren ini diteruskan oleh K.H Nasyir ( 1870 - 1900 ) K.H M arief ( 1900 - 1920 ) Kyai Sueb ( 1920 - 1937 ) K.H Masduki ( 1937 - 1942 ) dan K.H Z abidin ( 1942 - 1957 ). Pada tahu 1957 pesantren ini sempat bubar karena adanya ganguaan keamanan,pengacauaan Dl/Tll sedang berkecamuk sehingga K.H Z Abidin yang memimpin pesantren dimasa itu menganggap perlu mengamankan diri demi menyelamatkan keberadaan pesantren dan para santrinya ada yang ikut mengungsi dengan gurunya dan ada pula yang ikut dengan saudarasaudaranya dikota lain yang dianggap aman.

Pada tahun 1963 setelah situasi aman K.H Ijudin yang akrab dengan panggilan Ama cipulus, sepulangnya menunaikan ibadah Haji berniat meneruskan perjuangan para leluhurnya dalam mengelola pesantren Ia anak K.H Sueb yang pernah memimpin pesantren tersebut pada priode 1920 - 1937, dengan keinginan serta tekad yang kuat untuk menyebarkan dakwah islam melalui pesantren, maka didirikanlah rumah yang dilengkapi dengan langgar sederhana diatas tanah wakaf seluas 0,25 Hektar dikampung cipulus kecamatan wanayasa. Perkembangan pesantren tersebut sangat pesat terbukti dengan jumlah santri terus meningkat, bahkan sebagain masyarakat sekitar yang ingin menuntut ilmu dirumah tersebut tidak tertampung, melihat kenyataan itu kemudian dibuatlah asrama pondokan yang sederhana, tiang dari kayu seadanya dengan dilapisi dinding dari bambu yang dikerjakan oleh para santri dan dibantu oleh masyarakat setempat walau demikian, asrama yang sederhana itu untuk sementara cukup menampung para santri, selang beberapa tahun diperluas menjadi 0,50 hektar dan pesantren tersebut diberi nama SUKA LAKSANA dan pada tahun 1975 atas saran para tokoh serta simpatisan nama peasantren suka laksana diganti menjadi pesantren Al-hikamussalafiyyah, yang berarti pesantren yang mengikuti jalan para ulama Salaf, Langkah yang dilakukan Ama menjadikan Pesantren Alhikamussalafiyah semakin terkenal disamping karena reputasi kelimuan KH.Ama Ijudin yang diakui dikalangan ulama juga tradisi mencetak kiayi di Pesantren Alhikamussalafiyah di anggap berhasil dibuktikan dengan banyaknya alumni yang menjadi tokoh agama dan masyarakat bahkan mendirikan pesantren sekaligus memimpinnya. Pada 
Asep Jamaludin, Sihabudin, Haerudin, Asep Darojatul Ramli Vol 5 No 1

ISSN : 2541-6995

E ISSN : 2580-5517

tanggal 15 mei 1985, bupati Purwakarta meresmikan pesantren cipulus sebagai Pusat Informasi Pesantren (PIP), yang bertujuan untuk menyukseskan pola pendidikan santri dengan rumusan $4 \mathrm{H}$,yaitu :

- Heart \{Hati\} mendidik santri terhadap iman,islam dan ihsan sehingga menjadi santri yang alim serta tangguh dalam menghadapi hambatan, rintangan ancaman dan sebagainya.

- Head \{Kepala\}mendidik santri untuk mencerdaskan kehidupan santri sesuai dengan pembukaan Undang-Undang Dasar 1945 dan pola berpikir pemerintah provinsi Jawa Barat yaitu akal cerdas akan melahirkan santri berilmu pengetahuan serta tanggap terhadap zaman.

- Hand \{Tangan\} mendidik santri supaya terampil dalam berbagai sikap sehingga mampu menjadi santri yang cekatan.

- Health \{Sehat\} mendidik santri supaya berolahraga untuk kesehatan jasmani dan rohani sehingga santri mencintai kebersihan dan kesehatan.

Yayasan Pondok Pesantren Al-Hikamussalafiyah pada tanggal 18 Juni 1986 \{10 syawal $1406 \mathrm{H}$ \} mendirikan madrasah diniah wustho, yang selanjut nya berdasarkan usulan dari masyarakat khususnya jama'ah pengajian yang menginginkan anak cucunya, ingin memiliki ijasah negri, maka Al-mukarom mama cipulus KH. Idjudin, menganjurkan ke putra nya KH. Muparoj yang akrab dengan panggilan KH. Hamid, untuk mendirikan sekolah yang lulusannya bisa melanjutkan ke sekolah yang lebih tinggi. Berdasarkan himbauaan tersebut salah seorang tokoh masyarakat yang bernama $\mathrm{H}$. Umar sanggup untuk membuatkan bangunannya, bahkan lebih dari itu hartanya yang berada dikomplek pesantren cipulus diwakapkan ke pesantren untuk kepentingan pendidikan pesantren. Dengan adanya dukungan seperti itu, pada pertengahan tahun 1987 madrasah diniah wustho menjadi Madrasah Tsanawiyah MTs, Kurikulum untuk sekolah MTs mengikuti kurikulum nasional dengan status di akui, alumni nya bisa melanjutkan pendidikan nya ke SMA atau Madrasah Aliyah dan dalam tahun yang sama MTs cipulus menjadi terakreditasi nilai B, untuk mencapai tujuan tersebut maka didirikan Yayasan Pondok Pesantren Alhikamussalafiyah yang berbadan Hukum,akte notaris no 14 tanggal 15 Agustus 1988 pada tahun yang sama tahun 1988 didirikan juga MA Madrasah Aliyah yang saat itu satus nya 
Asep Jamaludin, Sihabudin, Haerudin, Asep Darojatul Ramli Vol 5 No 1

ISSN : 2541-6995

E ISSN : 2580-5517

baru terdaftar, tenaga pengajarnya pun seadanya karena belum bisa meminta bantuan dari pihak luar, dan ujian nasionalnya di titipkan kepada MAN subang dan pada tahun 1989 satatus nya menjadi di akui dan ikut ujian kepada MAN Purwakarta dan pada tahun 1991 Madrasah Aliyah MA YPPA Cipulus terakreditasi nilai B \{ Surat Keputusan Kepala Kantor Wilayah DEPAG Propinsi Jawa Barat nomor: W.i/I/HK.008/562/1991 \}Dengan perkembangan yang demikian pondok pesantren Cipulus, telah mempunyai garis besar kebijakan pesantren yang kemudian disempurnakan menjadi pola dasar dan pembinaan Pondok Pesantren Al-Hikamussalafiyah yang berasaskan (1)Tafaqquh fid dien (2) Da'wah, (3)Taawaun, (4) Musyawarah, (5) Ukhuwah Islamiyah, dan bertujuan jangka panjang membina dan mengembangkan ketawaan kepada Allah SWT mengembangkan keilmuan yang bermanfaat dan pengabdian terhadap agama masyarkat dan negara dengan sasaran memiliki standar pendidikan yang baik dengan mengembangkan pendidikan dengan sistem terpadu dan metodhe pendidikan yang baru,menjalin kerja sama dengan berbagai pihak dalam rangka peningkatan mutu efektifitas pendidikan, Kurikulum untuk sekolah MA YPPA Cipulus mengikuti kurikulum nasional sedang kitab yang dipelajari di pesantren masih mempertahankan kitab klasik baik dibidang Aqidah, Fiqh maupun Tasauf, KH. Ijudin dalam memajukan Pesantren Al-Hikamussalafiyah Cipulus dibantu oleh Putra putri dan para menantunya yang mana menantunya tersebut semua murid beliau yang di nikahkan dengan putri dan putra nya.

Ada pun unit-unit pendidikan yang diselenggarakan di Yayasan Pondok Pesantren AlHikamussalafiyah yaitu sebagai berikut :

\section{Taman Kanak-Kanak Al-Qur'an/TKQ}

Yang bertanggung jawab sekaligus sebagai Kepala Sekolah Yaitu Hj. Yuyu Rufaedah Arkah yang menikah dengan KH. Sa'dudin.

2.Pesantren kanak-kanak, berasrama, putra dan putri\{Al-Banun/albanat\} Yang bertanggung jawab dari putra KH. Adang Badrudin yaitu KH. Hasbi

3.Madrasah Diniyah/Sekolah Agama

Yang bertanggung jawab sekaligus sebagai Kepala sekolah yaitu KH. Muhammad Asep

Muslim Abu Haizin Putra bungsu Mama Cipulus yang menikah dengan Hj. Imas 4.Madrasah Tsanawiyah/MTs 
Asep Jamaludin, Sihabudin, Haerudin, Asep Darojatul Ramli Vol 5 No 1

ISSN : 2541-6995

E ISSN : 2580-5517

Yang bertanggung jawab Sekaligus sebagai Kepala Sekolah yaitu Iban Bunyamin, MPd. Beliu putra almarhum KH.Mufaroj

5.Madrasah Aliyah/MA Islam

Yang bertanggung Jawab sekaligus sebagai kepala Sekolah Yaitu KH. Muhammad Ansor yang menikah dengan Hj. Nyimas Nasiroh Arkah Putri cikal nya Mama Cipulus. 5.Cabang Pondok Pesantren Al-Hikamussalafiyah Mambaul'ulum

Yang bertanggung jawab sekaligus Pimpinan yaitu KH. Ma'mun Munawar yang menikah dengan $\mathrm{Hj}$. Nani Arkah putri Mama Cipulus (http://wecarso.blogspot.com/2009/11/sejarah-singkat-pesantren-al.html, diakses senin 20 Agustus 2019) dan (https://harga.web.id/pendaftaran-dan-biaya-pendidikan-pondokpesantren-cipulus-ta-2018-2019.info, diakses senin 20 aAgustus 2019).

\section{Hasil Penelitian}

Setelah peneliti mengumpulkan data di lapangan, selanjutnya peneliti menuangkan data hasil penelitian yang nantinya akan menjawab permasalahan -permasalahan yang telah dirumuskan, diantaranya yaitu : untuk menjawab rumusan masalah pertama tentang bagaimana manajemen yang diterapkan di pondok pesantren al hikamussalafiyyah peneliti mewawancarai pengasuh pondok pesantren dan beberapa guru - guru yang mengajar di pondok pesantren yang dituangkan di bawah ini :

Tabel . 1.1 Wawancara dengan Pengasuh Pondok Pesantren Al hikamussalafiyyah KH. Adang Baddrudin pada 25 Juni 2019

\begin{tabular}{l|l|l}
\hline \multicolumn{1}{c|}{ NO } & \multicolumn{1}{|c}{ Pertanyaan } & \multicolumn{1}{c}{ Jawaban } \\
\hline 1 & $\begin{array}{l}\text { Manajemen yang bagaimana } \\
\text { yang diterapkan di pondok } \\
\text { pesantren untuk menagkal paham } \\
\text { radikalisme? }\end{array}$ & $\begin{array}{l}\text { Dalam memenaj pondok pesantren agar } \\
\text { santri tidak berpaham radikal di sini kami } \\
\text { mengatur semua kegiatan santri - santri } \\
\text { sehari hari dari bangun tidur sampai } \\
\text { mereka hendak tidur kembali, tenaga } \\
\end{array}$ \\
& $\begin{array}{l}\text { pengajarnya juga kami pilih yang tidak } \\
\text { berpaham radikal, juga pelajaran - dan }\end{array}$
\end{tabular}


Asep Jamaludin, Sihabudin, Haerudin, Asep Darojatul Ramli Vol 5 No 1

ISSN : 2541-6995

E ISSN : 2580-5517

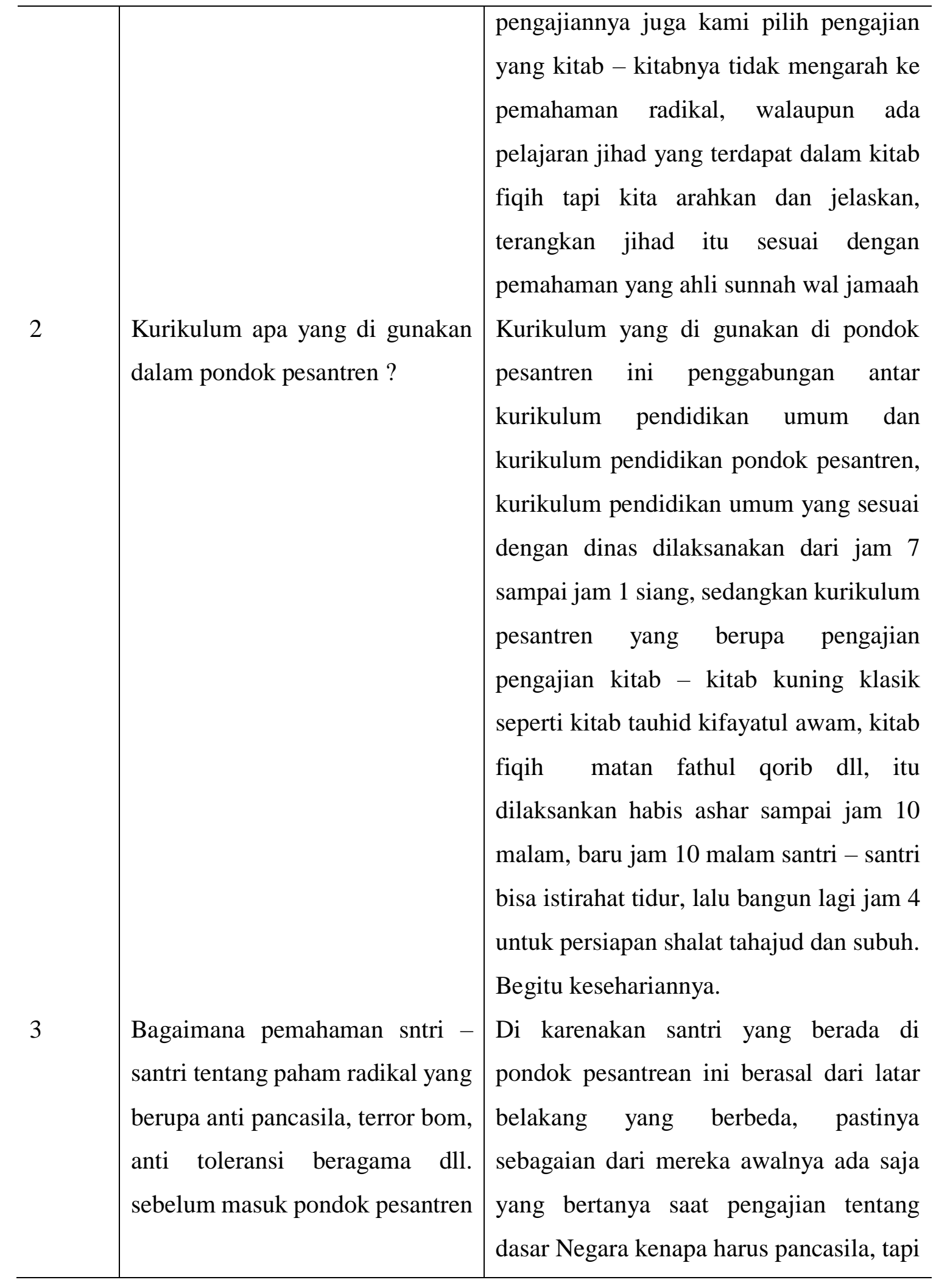


Asep Jamaludin, Sihabudin, Haerudin, Asep Darojatul Ramli Vol 5 No 1

ISSN : 2541-6995

E ISSN : 2580-5517

alhamdulilah lama kelamaan ketika mereka belajar agama di pondok ini mereka di berikan pemahaman yang benar sehingga mereka sadar dan tidak mempunyai lagi pemahaman dan pemikiran tentang kenapa pancasila sebagai dasar Negara kita? Dari segi toleransi beragama juga awlanya mereka ada yang bertanya kenapa kita harus bertoleran terhadap agama lain, padahal agama yang paling benar itu agama islam, maka setelah mereka mendapatkan penjelasan mereka kahirnya jadi paham dan mengerti tentang pentingnya toleransi antar umat beragama.

Dari hasil wawancara dengan pengasuh pondok pesantren yang telah disebutkan, bahwa manajemen pesantren yang diterapkan mencakup mengatur semua aspek kehidupan santri dalam kesehariannya, kajian - kajian sehari - harinya, juga guru - guru yang mengajarnya pun dipilih sehingga tidak ada yang berpaham radikal akan tetapi berpaham ahli sunnah waljamaah.

Kemudian untuk menjawab rumusan masalah yang ke dua tentang ada tidaknya peran pesantren dalam menangkal paham radikalisme pada diri santri, peneliti membuat angket yang di bagikan kepada 90 santri - santri pondok pesantren, berikut ini angket wawancara yang di bagikan pada santri - santri :

Tabel. 1.2 Tabel Angket Hasil Penelitian Santri

\begin{tabular}{|l|l|l|l|l|}
\hline \multirow{2}{*}{$\begin{array}{l}\text { Indikator } \\
\text { Petanyaan }\end{array}$} & \multicolumn{2}{|c|}{ Jawaban } & \multirow{2}{*}{$\%$} \\
\cline { 3 - 4 } & Setuju & Tidak setuju & Tidak tahu & \\
\hline
\end{tabular}


Asep Jamaludin, Sihabudin, Haerudin, Asep Darojatul Ramli

Vol 5 No 1

ISSN : 2541-6995

E ISSN : 2580-5517

\begin{tabular}{|c|c|c|c|c|}
\hline $\begin{array}{l}\text { Apakah anda setuju jika } \\
\text { agama islam harus } \\
\text { disebarkan dengan cara } \\
\text { apapun termasuk dengan } \\
\text { cara kekerasan di } \\
\text { Indonesia? }\end{array}$ & 85 & 0 & 5 & $\begin{array}{l}94,4 \quad \% \\
\text { setuju, } 5,6 \\
\% \text { tidak } \\
\text { tahu }\end{array}$ \\
\hline $\begin{array}{l}\text { Apakah anda setuju } \\
\text { dengan perilaku bom } \\
\text { bunuh diri yang selama } \\
\text { ini terjadi diIndonesia? }\end{array}$ & 90 & 0 & 0 & $\begin{array}{l}100 \% \\
\text { setuju }\end{array}$ \\
\hline $\begin{array}{l}\text { Apakah anda setuju } \\
\text { dengan idiologi pancasila } \\
\text { sebagai dasar negara } \\
\text { indonesia? }\end{array}$ & 90 & 0 & 0 & $\begin{array}{l}100 \% \\
\text { setuju }\end{array}$ \\
\hline $\begin{array}{l}\text { Apakah anda setuju } \\
\text { dengan pernyataaan } \\
\text { bahwa sebagai umat islam } \\
\text { kita harus menghormati } \\
\text { dan menghargai penganut } \\
\text { agama lain? }\end{array}$ & 90 & 0 & 0 & $\begin{array}{l}100 \% \\
\text { setuju }\end{array}$ \\
\hline $\begin{array}{l}\text { Jika dilingkungan tempat } \\
\text { tinggal anda ada } \\
\text { pembangunan tempat } \\
\text { ibadah agama lain, } \\
\text { apakah anda setuju jika } \\
\text { ada kelompok umat islam } \\
\text { yang menghalangi } \\
\text { pembangunan tempat } \\
\text { ibadah tersebut? }\end{array}$ & 0 & 80 & 10 & $\begin{array}{l}88,9 \% \\
\text { santri } \\
\text { setuju } \\
, 11,1 \text { tidak } \\
\text { tahu }\end{array}$ \\
\hline 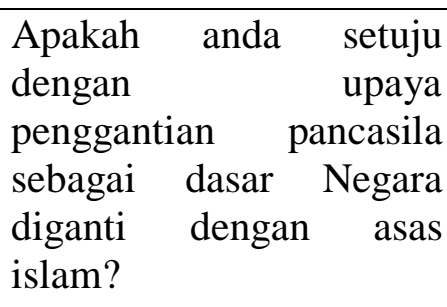 & 0 & 90 & 0 & $\begin{array}{l}100 \% \\
\text { tidak } \\
\text { setuju }\end{array}$ \\
\hline $\begin{array}{l}\text { Apakah anda setuju } \\
\text { dengan upaya sebagian } \\
\text { kelompok islam yang } \\
\text { hendak memformalkan } \\
\text { syariat islam melalui } \\
\text { undang - undang atau } \\
\text { peraturan daerah? }\end{array}$ & 70 & 0 & 20 & $\begin{array}{l}77,8 \\
\text { setuju, } \\
22,2 \text { tidak } \\
\text { tahu }\end{array}$ \\
\hline Apakah anda setuju & 90 & 0 & 0 & $100 \%$ \\
\hline
\end{tabular}


Asep Jamaludin, Sihabudin, Haerudin, Asep Darojatul Ramli

Vol 5 No 1

ISSN : 2541-6995

E ISSN : 2580-5517

\begin{tabular}{|c|c|c|c|c|c|}
\hline $\begin{array}{l}\text { dengan upaya } \\
\text { sekelompok umat islam } \\
\text { yang hendak menegakkan } \\
\text { khilafah islamiyyah? }\end{array}$ & & & & & setuju \\
\hline \multirow{2}{*}{ Indikator Pertanyaan } & \multicolumn{5}{|c|}{ Jawaban } \\
\hline & Tahu & $\begin{array}{c}\text { Pernah } \\
\text { Mendengar }\end{array}$ & \multicolumn{2}{|c|}{ Tidak tahu } & \\
\hline $\begin{array}{l}\text { Apakah anda mengetahui } \\
\text { atau pernah mendengar } \\
\text { tentang keberadaan } \\
\text { kelompok dalam islam } \\
\text { yang menggunakan cara } \\
\text { kekerasan seperti terror } \\
\text { bom dan lain sebagainya? }\end{array}$ & 40 & 35 & \multicolumn{2}{|c|}{15} & $\begin{array}{l}44,4 \text { santri } \\
\text { tahu, 38,9 } \\
\text { pernah } \\
\text { dengar, } \\
16,7 \text { tidak } \\
\text { tahu }\end{array}$ \\
\hline \multirow[t]{2}{*}{ Indikator Pertanyaan } & \multicolumn{5}{|c|}{ Jawaban } \\
\hline & Internet & Guru & $\begin{array}{c}\text { Yang } \\
\text { lainnya }\end{array}$ & $\begin{array}{c}\text { Tidak } \\
\text { tahu }\end{array}$ & \\
\hline $\begin{array}{l}\text { Dari mana anda } \\
\text { tahu keberadaan } \\
\text { aliran tersebut? }\end{array}$ & 48 & 20 & 12 & 10 & $\begin{array}{l}53,3 \\
\text { internet,2 } \\
2,2 \text { guru, } \\
13,3 \text { yang } \\
\text { lainnya, } 11 \\
, 1 \text { tidak } \\
\text { tahu } \\
\end{array}$ \\
\hline \multirow{2}{*}{$\begin{array}{l}\text { Indikator } \\
\text { Pertanyaan }\end{array}$} & \multicolumn{5}{|c|}{ Jawaban } \\
\hline & Tahu & $\begin{array}{l}\text { Pernah } \\
\text { dengar }\end{array}$ & \multicolumn{2}{|c|}{ Tidak tahu } & \\
\hline $\begin{array}{l}\text { Apakah anda tahu ajaran } \\
\text { kelompok } \\
\text { tersebut? }\end{array}$ & 32 & 50 & \multicolumn{2}{|l|}{8} & $\begin{array}{l}35,6 \text { tahu, } \\
55,6 \\
\text { pernah } \\
\text { dengar, } 8, \\
9 \text { tidak } \\
\text { tahu }\end{array}$ \\
\hline \multirow{2}{*}{$\begin{array}{l}\text { Indikator } \\
\text { pertanyaan }\end{array}$} & \multicolumn{4}{|c|}{ Jawaban } & \\
\hline & Mengikuti & $\begin{array}{c}\text { Tidak } \\
\text { mengikuti }\end{array}$ & \multicolumn{2}{|c|}{ Tidak tahu } & \\
\hline $\begin{array}{l}\text { Apakah anda } \\
\text { mengikuti } \\
\text { kelmpok radikal } \\
\text { tersebut? }\end{array}$ & 0 & 90 & & & $\begin{array}{l}100 \% \\
\text { tidak } \\
\text { mengikuti }\end{array}$ \\
\hline \multirow{2}{*}{$\begin{array}{l}\text { Indikator } \\
\text { pertanyaan }\end{array}$} & \multicolumn{5}{|c|}{ Jawaban } \\
\hline & Setuju & $\begin{array}{l}\text { Tidak } \\
\text { setuju }\end{array}$ & & lak tahu & \\
\hline
\end{tabular}


Asep Jamaludin, Sihabudin, Haerudin, Asep Darojatul Ramli

Vol 5 No 1

ISSN : 2541-6995

E ISSN : 2580-5517

\begin{tabular}{l|l|l|l|l}
\hline $\begin{array}{l}\text { Apakah anda setuju jika } \\
\text { dikatakan } \begin{array}{r}\text { bahwa } \\
\text { kebenaran islam itu hanya } \\
\text { ada dikelompok tertentu } \\
\text { saja? }\end{array}\end{array}$ & 85 & 5 & $\begin{array}{l}94,4 \text { tidak } \\
\text { setuju, 5,6 } \\
\text { tidak tahu }\end{array}$ \\
\hline
\end{tabular}

Dari data angket yang dibagikan kepada santri - santri dapat dideskripsikan sebgai berikut :

Pertanyaan pertama tentang Apakah anda setuju jika agama islam harus

disebarkan dengan cara apapun termasuk dengan cara kekerasan di Indonesia ?

Hasil dari pertanyaan tersebut santri -santri hampir semuanya menjawab tidak setuju sekitar 94,4 \% mereka tidak menyetujui islam disebarkan dengan cara kekerasan, dan sebagian kecil sekitar 5,5\% tidak tahu. Artinya sebagian besar santri tidak setuju jika islam disebarkan dengan cara kekerasan dengan memaksakan kehendak, dan menyetujui penyebaran islam itu dengan cara yang baik, damai dan lemah lembut.

Pertanyaan kedua tentang : Apakah anda setuju dengan perilaku bom bunuh diri yang selama ini terjadi diIndonesia?

Dari pertanyaan kedua ini semua santri atau $100 \%$ tidak setuju dengan bom bunuh diri yang dilakukan sebagian orang, karena islam tidak mengajarkan seperti itu sesuai yang dipelajari di pondok.

Pertanyaan ketiga yaitu : Apakah anda setuju dengan idiologi pancasila sebagai dasar negara indonesia?

Dari pertanyaan ketiga juga semua santri $100 \%$ setuju dengan idiologi pancasila karena ini memang sesuai dengan yang di pelajari idiologi pancasila sudah dirumuskan oleh para pendahulu indonesia.

Pertanyaan keempat : Apakah anda setuju dengan pernyataaan bahwa sebagai umat islam kita harus menghormati dan menghargai penganut agama lain?

Dari pertanyaan ini semu santri $100 \%$ setuju dengan sikap saling menghormati dengan orang yang beragama lain, Karena ini juga merupakan yang diajarakan oleh agama islam. 
Asep Jamaludin, Sihabudin, Haerudin, Asep Darojatul Ramli Vol 5 No 1

ISSN : 2541-6995

E ISSN : 2580-5517

Pertanyaan kelima : Jika dilingkungan tempat tinggal anda ada pembangunan tempat ibadah agama lain, apakah anda setuju jika ada kelompok umat islam yang menghalangi pembangunan tempat ibadah tersebut?

Dari pertanyaan ini $88,9 \%$ santri menyatakan tidak setuju dan $11,1 \%$ santri menyatakan tidak tahu.

Pertanyaan keenam : Apakah anda setuju dengan upaya penggantian pancasila sebagai dasar Negara diganti dengan asas islam?

Dari pertanyaan ini semua santri tidak setuju 100\% karena idiologi pancasila itu merupakan pemersatu Indonesia, yang mana Indonesia itu bermacam - macam budayanya, agama, ras, bahasa, dll.

Pertanyaan ketujuh : Apakah anda setuju dengan upaya sebagian kelompok islam yang hendak memformalkan syariat islam melalui undang - undang atau peraturan daerah?

Dari pertanyaan ini 77,8 \% santri menjawab tidak setuju, 22,2\% santri menjawab setuju dan santri tidak tahu.

Pertanyaan kedelapan : Apakah anda setuju dengan upaya sekelompok umat islam yang hendak menegakkan khilafah islamiyyah?

Dari pertanyaan ini semua santri $100 \%$ menjawab tidak setuju.

Pertanyaan kesembilan : Apakah anda mengetahui atau pernah mendengar tentang keberadaan kelompok dalam islam yang menggunakan cara kekerasan seperti terror bom dan lain sebagainya?

Dari pertanyaan ini 44,4 \%santri tahu, 38,9\% pernah dengar, $16,7 \%$ tidak tahu.

Pertanyaan kesepuluh : Dari mana anda tahu keberadaan aliran tersebut?

Dari pertanyaan ini santri yang menjawab 53,3\% internet, 22,2\% guru, 13,3\% yang lainnya, 11,1 tidak tahu.

Pertanyaan kesebelas : Apakah anda tahu ajaran kelompok radikal tersebut?

Dari pertanyaan ini 35,6\% tahu, 55,6\% pernah dengar, 8,9\% tidak tahu.

Pertanyaan kedua belas : Apakah anda mengikuti kelmpok radikal tersebut? 
Asep Jamaludin, Sihabudin, Haerudin, Asep Darojatul Ramli Vol 5 No 1

ISSN : 2541-6995

E ISSN : 2580-5517

Dari pertanyaan ini semua santri $100 \%$ tidak ada yang mengikuti kelompok radikal tersebut.

Pertanyaan ketiga belas : Apakah anda setuju jika dikatakan bahwa kebenaran islam itu hanya ada dikelompok tertentu saja?

Dari pertanyaan ini yang menjawab $0 \%$ menjawab setuju 94,4\% tidak setuju, 5,6\% tidak tahu

Dari hasil angket yang telah dibagikan kepada 90 pondok pesantren al hikamussalafiyah cipulus dapat disimpulkan, manajemen pondok pesantrean yang terapkan berdampak positif pada pemahaman santri - santri sehingga mereka tidak mempunya pemahaman yang radikal.

\section{PENUTUP}

Manajemen di pondok pesantren Al hikamussalafiyyah menitik beratkan pada pendidikan perilaku sehari - hari santri, juga mengedepankan pengajian - pengajian keagamaan yang pemahamannya nati radikal, akan tetapi pemahamnnya sesuai dengan manhaj ahli sunnah waljamaah.

\section{DAFTAR PUSTAKA}

Departemen Agama RI, Al-Qur'an dan Terjemahannya dengan Transliterasi Perbasis, Jakarta: Asy-Syifa.

Ismail, F. 2014, Dinamika Kerukunan Antarumat Beragama; Konflik, Rekonsiliasi, dan Harmoni, Cet.I; Bandung: Remaja Rosdakarya.

Shihab, Q. Tafsir al-MIsbah: Pesan, Kesan, dan Keserasian al-Qur'an Vol, 6. Alwasilah, H. 2011, Pokoknya Kualitatif: Dasar-Dasar Merancang dan Melakukan Penelitian Kualitatif ,Jakarta: Dunia Pustaka.

Judistira, K, 2008, Dasar dan Proses Penelitian Sosial, Bandung; Primaco Akademika. Margono, S., 1997 Metodologi Penelitian Pendidika,Jakarta: Renika Cipta. Wahyu, 1996, Pedoman Penelitian Pendidikan, Bandung: Tarsito. 
Asep Jamaludin, Sihabudin, Haerudin, Asep Darojatul Ramli Vol 5 No 1

ISSN : 2541-6995

E ISSN : 2580-5517

http://wecarso.blogspot.com/2009/11/sejarah-singkat-pesantren-al.html, Sejarah singkat Al hikamussalafiyyah cipulus, diakses senin 20 Agustus 2019.

https://harga.web.id/pendaftaran-dan-biaya-pendidikan-pondok-pesantren-cipulus-ta2018-2019.info, Sejarah Pondok pesantren Cipulus. diakses senin 20 Agustus 2019. 